\title{
Cholinesterase concentration in three types blood of cattle raised on exposed land by Organophosphates
}

\author{
Ali Harokan ${ }^{1}$, Totong Kamaluddin ${ }^{2}$, Daniel Saputra ${ }^{2}$, Nurhayati Damiri ${ }^{2,3^{*}}$ \\ ${ }^{1}$ Student of Doctoral Program of Enviromental Science, Graduate school, Universitas Sriwijaya \\ ${ }^{2}$ Lecturer of Doctoral Program of Enviromental Science, Graduate School, Universitas Sriwijaya \\ ${ }^{3}$ Lecturer of Pest and Plant Diseases Department, Faculty of agriculture, Universitas Sriwijaya \\ *Corresponding Author:nurhayati@fp.unsri.ac.id
}

Article history

\begin{tabular}{llll} 
Received & Received in revised form & Accepted & Available online \\
06 March 2021 & 15 April 2021 & 30 April 2021 & 01 May 2021 \\
\hline
\end{tabular}

\begin{abstract}
Organophosphate pesticides are one of the causes of contamination in animal feed. The cholinesterase enzyme test is used to diagnose toxic exposure due to organophosphate pesticides. Quantitative research with cross sectional survey design used 35 samples of cattle. The study was conducted in March - September 2020. Concentration measurement on cholinesterase enzyme concentrations of blood plasma used the biosystem A15 DGKC-Colorimetric Kinetic method. This study aims to evaluate the concentration of the enzyme cholinesterase as a marker of organophosphate poisoning in cattle. Blood samples were collected from the ventrolateral neck veins of bulls and cows aged 1-7 years which collected from local breeders in the Ogan Ilir area. The results showed that the cattle raised on exposed land by organophosphate pesticides as concentration decreasing indication of cholinesterase enzyme in cows plasma. Cholinestrase enzyme levels in cows were $0.20 \pm 0.067 \mathrm{U} / \mathrm{ml}$ and bulls were $0.27 \pm 0.183 \mathrm{U}$ $/ \mathrm{ml}$. The highest concentration of cholinesterase enzyme levels were occurred in cattle aged 2 years, $0.25 \pm 0.34 \mathrm{U} /$ $\mathrm{ml}$ and the lowest was in cattle aged 7 years, $0.12 \pm 0.04 \mathrm{U} / \mathrm{ml}$.
\end{abstract}

Key words: Cholinesterase, Environment, Cattle, Organophosphate, Plasma

\begin{abstract}
Abstrak. Pestisida organofosfat merupakan salah satu penyebab kontaminasi pada pakan ternak. Pemeriksaan enzim cholinesterase digunakan untuk mendiagnosis pemaparan keracunan akibat pestisida organofosfat. Penelitian kuantitatif dengan desain survei menggunakan desain cross sectional dengan menggunakan 35 sampel sapi. Penelitian dilakukan pada bulan Maret - September 2020. Pengukuran Kadar konsentrasi enzim cholinesterase plasma darah menggunakan alat biosystem A15 metode DGKC-Colorimetric Kinetic. Penelitian ini bertujuan untuk mengevaluasi kadar konsentrasi enzim kolinesterase sebagai penanda keracunan organofosfat pada sapi. Sampel darah diambil dari vena ventrolateral leher sapi jantan dan betina berumur 1-7 tahun dikumpulkan dari peternak lokal di wilayah OganIlir. Hasil penelitian menunjukkan bahwa sapi yang dibudidayakan di peternak terpapar pestisida organofosfat yang ditunjukkan dengan penurunan konsentrasi dan kadar enzim kolinesterase dalam plasma sapi betina. Kadar

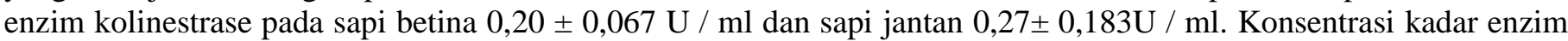
kolinesterase tertinggi berdasarkan usia sapi jantan dan betina terjadi pada sapi umur 2 tahun yaitu 0,25 $\pm 0,34 \mathrm{U} /$ $\mathrm{ml}$ dan terendah pada sapi umur 7 tahun yaitu $0,12 \pm 0,04 \mathrm{U} / \mathrm{ml}$.
\end{abstract}

Kata kunci: Cholinesterase, Lingkungan, Sapi, Organofosfat, Plasma

\section{Introduction}

Pesticides are strong acid esters or phenols which can cause skin irritation, redness and dermatitis on the skin. Its use can cause nervous system disorders. Which occured in the peripheral nerves and central nervous system[1]. Contaminated animal feed is the main source of pesticide entry into the livestock[2].

Pesticides have lipophilic properties that 
could be stored in the fatty tissue of the animal's body. Pesticide residues present in feed which eaten by livestock will transfer to meat through the food supply chain as a result, then animal products such as meat containing pesticide residues that endanger public health[3].

Organophosphate pesticides are able to inhibit the activity of the cholinesterase enzyme through nerve impulse mechanism by binding cholinesterase, so that acetylcholine hydrolysis does not occur. The inhibition of cholinesterase activity may last from a few hours to several weeks depending on the type of anticholinesterase. Acetylcholine is a neurotransmitter located between the nerve endings and muscles which has functions continuing stimulation to nerves[4].

Acetylcholinesterase activity plays a role during the acetylcholine-assisting inflammatory response. Acetylcholinesterase enzymes biologically has function to help the neurotransmitter acetycholine as an anti-inflammatory mediator. Choline ester acetylcholinesterase is produced by many cells, including lymphocytes in the blood and central nervus system [5]. This study aims to evaluate the levels of the cholinesterase enzyme concentration as a marker of organophosphate poisoning in cattle.

\section{Materials and Methods}

This research was carried out in farm in OganIlir Regency. The research was conducted in March-September 2020. The equipmentand materials used in this study were: Blood tube $(3 \mathrm{ml}$ non heparin red color), cooler box, Eppendorf, needdle BD vacu $21 \mathrm{G}$, holder vacutainer, centrifugation at $10000 \mathrm{rpm}$ ( Centurion, UK)) and biosystem A15. The tool used to analyze the cholinesterase enzyme was biosystem A15. These research was a quantitative study with a survey cross sectional design. In this study, sample selection used simple random sampling technique. The number of samples used the formula below:

$$
\frac{\mathrm{n}=\mathrm{Z} \alpha^{2} \times \mathrm{P} \times \mathrm{Q}}{\mathrm{L}^{2}}
$$

Information:

$\mathrm{n} \quad=$ Minimum sample size required

$\mathrm{Za}=$ The standard value of the distribution corresponds to $\mathrm{a}=5 \%=1.96$
$\mathrm{P}=$ Prevalence of outcomes $30 \%$

$\mathrm{Q}=1-\mathrm{P}$

$\mathrm{L}=$ Level of Accuracy 10

$\mathrm{n}=\frac{(1.96)^{2} \times 0.3 \times 0.3=34,57 \text { (35 sample) }}{(0.1)^{2}}$

Blood samples were taken in the ventrolateral neck vein of cattle aged 1-7 years. DGKCColorimetric Kinetic method us biosystem A15. The working principle of DGKC - Colorimetric Kinetic is Butyrylthiocholine $+\mathrm{H} 2 \mathrm{O}$ CHE Thiocholine + Butyric acid. In this study, there were 35 cattle consisting of 3 bulls and 32 cows. Cattle blood was centrifuged at $10000 \mathrm{rpm}$ for 10 minutes to collect blood plasma. Then the blood plasma was analyzed using the biosystem A-15. The control serum is carefully opened from the bottle and add $5 \mathrm{ml}$ of aquabides, The control serum container is closed again then stir slowly for 30 minutes by avoidding the formation of foam, then enter the control serum into the sample cup. Carrying out control is carried out by using biosystem A- 15 .

Parameters observed in the study were included cholinesterase concentrationin cattle plasma, differences in mean sex and mean age of cattle using pearson's statistical test. The data collected were analyzed both tabulated and statistical SPSS version 16. Concentrations of cholinesterase enzyme levels with the DGKC-Colorimetric Kinetic method used the biosystem A15.

\section{Results and Discussion}

\section{Characteristics of cattle}

The characteristics based on the type of cattle are listed in Table 1: Types of cattle available to breeders

\begin{tabular}{ll}
\hline \multicolumn{1}{c}{ Type of cattle } & Percentages \\
\hline PO (Ongole breeding) & 74.3 \\
Brahman & 5.7 \\
Local Cattle & 8.6 \\
Brangus & 2.9 \\
Bali & 8.6 \\
\hline
\end{tabular}

Table 1, shows the types of cattle available in the farm are Ongole breeding (PO) $(74.3 \%)$, Brahman $(5.7 \%)$, local cattle $(8.6 \%)$, Brangus $(2.9 \%)$ and Bali. (8.6\%).

http://dx.doi.org/10.22135/sje.2021.6.1.67-72

68 
The content of cholinesterase in cattle blood plasma

Cholinesterase enzyme concentration

cattle according to sex are presented in Table 2

Table 2.Cholinesterase enzyme levels in blood plasma of male and female cattle.

\begin{tabular}{|c|c|c|c|c|c|c|c|}
\hline \multirow[t]{2}{*}{ Sex } & \multirow[t]{2}{*}{$\begin{array}{l}\text { Mean cholinesterase } \\
\text { enzyme levels }(\mathrm{U} / \mathrm{ml})\end{array}$} & \multirow[t]{2}{*}{$\begin{array}{l}\text { Standard } \\
\text { Deviation }\end{array}$} & \multirow[t]{2}{*}{$\begin{array}{l}\text { Standar } \\
\text { d Error }\end{array}$} & \multicolumn{2}{|c|}{$\begin{array}{l}95 \% \text { Confidence } \\
\text { Interval for mean }\end{array}$} & \multirow[t]{2}{*}{ Min } & \multirow[t]{2}{*}{ Max } \\
\hline & & & & Lower & Upper & & \\
\hline Male & 0.27 & 0.183 & 0.105 & 0.17 & 0.73 & 0.12 & 0.48 \\
\hline Female & 0.20 & 0.067 & 0.011 & 0.17 & 0.22 & 0.06 & 0.30 \\
\hline
\end{tabular}

Table 2, presented the cholinesterase enzyme concentration in male an average value of $0.27 \mathrm{U} / \mathrm{ml}$, higher than the cholinesterase enzyme levels in female of $0.20 \mathrm{U} / \mathrm{ml}$. However, the value of cholinesterase enzyme levels in the plasma of cattle has been decrease as indicatore organophosphate pesticides exposure.



Figure 1. Average levels of the cholinesterase enzyme in the blood of cattle according to sex
Cholinesterase enzyme using the Ellman method, the initial mean value of acetylcholinesterase was $624.65 \pm 39.32 \mathrm{IU} / \mathrm{L}$. Cholinesterase enzyme in the control group in blood plasma was $0.220 \pm$ $0.083 \mathrm{IU} / \mathrm{ml}[6]$. Cattle raised in farm have been exposed to organophosphate pesticides. It was indicated by the levels of the cholinesterase enzyme in blood plasma. Cholinesterase enzyme levels in cattle were $0.20 \mathrm{U} / \mathrm{ml}$.

Cholinesterase enzyme levels in cattle blood plasma.

Analysis of the cholinesterase enzyme level test in cattle by age was presented in Table 3

Table 3. Cholinesterase enzyme levels in cattle plasma by age.

\begin{tabular}{clrrrrrr}
\hline Age & $\begin{array}{l}\text { Mean cholinesterase } \\
\text { enzyme } \\
\text { activity(U/ml) }\end{array}$ & $\begin{array}{l}\text { Standard } \\
\text { Deviation }\end{array}$ & $\begin{array}{l}\text { Standard } \\
\text { Error }\end{array}$ & $\begin{array}{l}\text { 95\% Confidence Interval } \\
\text { for mean } \\
\text { Lower bound }\end{array}$ & $\begin{array}{l}\text { Min } \\
\text { Upper } \\
\text { bound }\end{array}$ & Max \\
\hline 2 & 0.25 & 0.34 & 0.19 & 0.17 & 0.34 & 0.24 & 0.30 \\
3 & 0.17 & 0.05 & 0.02 & 0.10 & 0.25 & 0.12 & 0.24 \\
4 & 0.23 & 0.04 & 0.01 & 0.19 & 0.26 & 0.18 & 0.30 \\
5 & 0.21 & 0.05 & 0.01 & 0.17 & 0.26 & 0.12 & 0.30 \\
6 & 0.16 & 0.07 & 0.03 & 0.08 & 0.25 & 0.06 & 0.30 \\
7 & 0.12 & 0.04 & 0.02 & 0.04 & 0.19 & 0.06 & 0.18
\end{tabular}

Table 3, cholinesterase levels in blood plasma in cattle aged 2 years $0.25 \pm 0.34,3$ years old $0.17 \pm 0.05,4$ years old $0.23 \pm 0.04,5$ years old $0.21 \pm 0.05,6$ years old $0.16 \pm 0.07$ and 7 years $0.12 \pm 0.04$. The highest and lowest cholinesterase levets in cattle blood plasma were 2 years old and 7 years old respectively. However, the value of cholinesterase levels in cattle blood plasma based

on age decreased on cattle aged 3 years, 5 years, 6 years and 7 years. The result is an overall reduction 
in cholinesterase, which indicated the cattle were exposed by organophosphate pesticide.

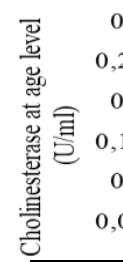

0,3
, 25
0,2
15
0,1
0,05

Type ear of yeCholinesterase enzyme Standard cow levels mean $(\mathrm{U} / \mathrm{ml})$

Deviation
Table 4.Cholinesterase enzyme levels in plasma by $\mathbf{t}$

Figure 2. Average levels of the cholinesterase enzyme in the blood of cattle at various ages Cholinesterase enzyme levels in the blood plasma of bulls and cows. The test analysis of the cholinesterase enzyme levels in cattle based on the type of cow were summarized in Table 4.

\begin{tabular}{|c|c|c|c|c|c|c|c|}
\hline & & & & bound & bound & & \\
\hline $\begin{array}{l}\text { PO } \\
\text { (Ongole } \\
\text { breeding) }\end{array}$ & 0.19 & 0.072 & 0.0142 & 0.164 & 0.223 & 0.06 & 0.30 \\
\hline $\begin{array}{l}\text { Local } \\
\text { Cattle } \\
\end{array}$ & 0.20 & 0.042 & 0.029 & 0.171 & 0.591 & 0.18 & 0.24 \\
\hline Bali & 0.23 & - & - & - & - & 0.24 & 0.24 \\
\hline
\end{tabular}

The analysis of the Pearson correlation test

Table 4, shows the cholinesterase enzyme levels in cow plasma has a mean value of $0.19 \mathrm{U} / \mathrm{ml}$ in $\mathrm{PO}$ (ongole breeding), $0.20 \mathrm{U} / \mathrm{ml}$ in local cattle and $0.23 \mathrm{Ul} / \mathrm{ml}$ in Bali cattle. The average cholinesterase levels in the blood of cattle by type of cow are listed in Figure 3.



Figure 3. Average levels of the cholinesterase enzyme in the blood of cattle from various types of cattle

Pearson Correlation Analysis to the concentration of the cholinesterase enzyme between age and cholinesterase enzyme levels is summarized in Table 5.

Table 5. Correlation analysis of Pearson age with cholinesterase enzyme levels

\begin{tabular}{ccc}
\hline & $\begin{array}{l}\text { Cholinesterase } \\
\text { Level Score }\end{array}$ & Enzyme \\
\hline Age score & $\mathrm{r}=-0.524$ \\
& $\mathrm{p}<0.001$ \\
$\mathrm{n}=35$ & \\
\hline
\end{tabular}

From, Table 5, the $\mathrm{p}$ value was 0.001 indicating significant correlation between age score and the cholinesterase enzyme level score. Pearson correlation value $\mathrm{r}=-0.524$ indicates strong relationship, and the direction of relationship is inverse (negatively correlated)

The normal cholinesterase enzyme $((\mu \mathrm{mol} / \mathrm{ml} /$ minute) was measured in cattle blood and plasma aged 3-6 months $0.39 \pm 0.11,1-2$ years $0.19 \pm 0.03$, 2 years old and above. $0.22 \pm 0.04$ [7]. Acetylcholinesterase concentrations in blood $5510 \pm$ 
$600 \mathrm{IU} / \mathrm{L}$ and $190 \pm 30 \mathrm{IU} / \mathrm{L}$ in blood plasma for cows aged 1 to 2 years [8].

Cholinesterases were a group of esterases that hydrolyze choline esters at a higher rate than other esters at the hydrolysis rate at optimum and controlled conditions .Cholinesterase was primarily responsible for the rapid removal of acetylcolinesterase within one millisecond after release at the cholinergic synapses, thus allowing proper temporal control of muscle contraction[9].

The in vivo test of sheep, goats and cattle showed cholinesterase inhibition by organophosphate malathion and diazinone insecticides. This insecticide had relatively low toxicity for pets. This pesticide can affect the animal after exposure causing cholinesterase inhibition at nerve endings then generate parasympathetic overstimulation[10].

Cholinesterase enzyme activity is related to genetic relationships, as well as a number of conditions that can decrease cholinesterase enzyme activity, such as liver disease, malnutrition, organophosphate poisoning, burns, renal failure, plasmaferesisi and drugs. Several conditions were associated with increased plasma cholineterase activity, thyroid disease, obesity, nephrotic syndrome and cognitive impairment[11].

Acetylcholinesterase was found in tissues conduction such as nerves and muscles, central and peripheral tissues, motor, sensory fibers, cholinergic and noncholinergic fibers. Acetylcholinesterase activity is higher in motor neurons than sensory neurons. Acetylcholinesterase is also found in the membranes of red blood cells as blood group antigens. In mammals the majority of acetylcholinesterase occurs as a tetrameric with a much smaller number of monomers[12].

In addition organophosphate pesticides, had the several potential metals to suppress activity, , such as $\mathrm{Hg}^{2+}, \mathrm{Cd}^{2+}, \mathrm{Cu}^{2+}$ and $\mathrm{Pb}^{2+}$. The potential effect of lead on erythrocyte acetylcholinesterase activity during metal exposure was used as a biomarker of lead-induced neurotoxicity in exposed subjects. Polycyclic aromatic hydrocarbons directly inhibit acetylcholinesterase. Polycyclic aromatic hydrocarbons were able to inhibit acetylcholinesterase activity in an addictive manner

Vol. 6 No. 1, 67-72 along with organophosphates to become a noncompetitive acetylcholinesterase inhibitor [13].

\section{Conclusion}

From the research results, it concluded that cultivated cattle has exposed by organophosphate pesticides indicated by concentration decreasing in the cholinesterase enzyme in cattle plasma. Cholinesterase enzyme levels in cattle were $0.20 \pm$ $0.067 \mathrm{u} / \mathrm{ml}$. The highest levels of cholinesterase enzymes occurred in cattle aged 2 year, $0.25 \pm 0.34$ $\mathrm{u} / \mathrm{ml}$ and the lowest in cattle aged 7 years, $0.12 \pm$ $0.04 \mathrm{u} / \mathrm{ml}$. Cholinesterase enzyme in the control group blood plasma was $0.220 \pm 0.083 \mathrm{IU} / \mathrm{ml}$. [6]

\section{Acknowledgements}

Thank you to the Department of Fisheries and Animal Husbandry, Ogan Ilir Distric.

\section{References}

[1] D. Kurniadi and E. Maywita, "Faktor-faktor Yang Berhubungan Dengan Keluhan Kesehatan Akibat Paparan Pestisida Pada Petani Hortikultura Di Desa Siulak Deras Mudik Kabupaten Kerinci," J. Menara Ilmu, vol. 12, no. 80, pp. 13-18, 2018. Available:https://jurnal.umsb.ac.id/index.php/ menarailmu/article/view/617/552

[2] S. K. Nag and M. K. Raikwar, "Persistent organochlorine pesticide residues in animal feed," Environ. Monit. Assess., vol. 174, no. 1-4, pp. 327-335, 2010, doi: 10.1007/s10661010-1460-1.

[3] N. Karabasanavar, S. P. Singh, A. H. Ahmad, S. K. Singh, and V. D. P. Rao, "Monitoring of Animal Feed and Fodder Samples for Endosulphan Residues," vol. 13, no. 2, pp. 119-122, 2015.

[4] M. Raini, "Toksikologi Pestisida dan Penanganan Akibat Keracunan Pestisida," Media Penelitian. dan Pengembangan. Kesehatan., vol. 17, no. 3, pp. 10-18, 2007. Available:http://ejournal.litbang.kemkes.go.id/ index.php/MPK/article/view/815/1660

[5] P. Glombowsky et al., "Cholinesterase's activities in cows supplemented with selenium, copper, phosphorus, potassium, and

http://dx.doi.org/10.22135/sje.2021.6.1.67-72 
magnesium intramuscularly during the transition period," Comp. Clin. Path., vol. 26, no. 3, pp. 575-579, 2017, doi: 10.1007/s00580-017-2423-5.

[6] V. T. Pardío, N. Ibarra, M. A. Rodríguez, and K. N. Waliszewski, "Use of cholinesterase activity in monitoring organophosphate pesticide exposure of cattle produced in tropical areas," J. Agric. Food Chem., vol. 49, no. 12 , pp. 6057-6062, 2001, doi: 10.1021/jf010431g.

[7] E. B. Abdelsalam and E. J. H. Ford, "Normal Esterase Activity in the Plasma, Whole Blood and Tissues of Cattle," Zbl. Vet. Med. A, vol. 32, no. 1-10, pp. 518-525, 1985, doi: 10.1111/j.1439-0442.1985. tb01972.x.

[8] E. J. Picco, H. R. Férnandez, D. C. Díaz David, M. I. San Andrés, J. C. Boggio, and C. Rodríguez, "Use of cholinesterase activity in monitoring chlorpyrifos exposure of steer cattle after topical administration," J. Environ. Sci. Heal. - Part B Pestic. Food Contam. Agric. Wastes, vol. 43, no. 5, pp. 405-409, 2008, doi: 10.1080/03601230802062158.

[9] S. Stepankova and K. Komers, "Cholinesterases and Cholinesterase Inhibitors," Curr. Enzym. Inhib., vol. 4, no. 4, pp. 160-171, 2008, doi: 10.2174 /157340808786733631.

[10] F. K. Mohammad, A. S. Alias, G. A. M. Faris, and B. K. Al-Baggou, "Application of an electrometric method for measurement of blood cholinesterase activities in sheep, goats and cattle treated with organophosphate insecticides," J. Vet. Med. Ser. A Physiol. Pathol. Clin. Med., vol. 54, no. 3, pp. 140143, 2007, doi: 10.1111/j.14390442.2007.00867.x.

[11] C. J.Cote, J. Lerman, and B. J. Anderson, "phamacokinetics and pharmacology of drugs used in children," in A practice of anesthesia for inflants and children (sixth Edition), ScinceDirect, 2019, pp. 100-176. Available:https://www.sciencedirect.com/scie nce/article/pii/B9780323429740000070

[12] M. B. Colovic, D. Z. Krstic, T. D. LazarevicPasti, A. M. Bondzic, and V. M. Vasic, "Acetylcholinesterase Inhibitors:
Pharmacology and Toxicology," Curr. Neuropharmacol., vol. 11, no. 3, pp. 315335, 2013, doi: 10. $2174 / 1570159 \mathrm{x}$ 11311030006.

[13] M. G. Lionetto, R. Caricato, A. Calisi, M. E. Giordano, and T. Schettino, "Acetylcholinesterase as a biomarker in environmental and occupational medicine: New insights and future perspectives," Biomed Res. Int., vol. 2013, 2013, doi: 10.1155/2013/321213. 